\title{
Aplikasi Penggunaan Konsentrat Pemacu Pertumbuhan untuk Penggemukan Sapi Potong di Karanganyar
}

\author{
Joko Riyanto *, Lutojo, dan Sunarto \\ Program Studi Peternakan, Fakultas Pertanian, Universitas Sebelas Maret, Surakarta \\ *Corresponding Author: jokoriyanto@staff.uns.ac.id
}

\begin{abstract}
ABSTRAK
KTT Maju Utomo dan Ngudi Berkah Desa Wonorejo Kecamatan Gondangrejo Karanganyar berusaha di bidang penggemukan sapi Simpo dan Limpo. Permasalahan yang dihadapi peternak adalah pertambahan berat badan harian sapi $0,2 \mathrm{~kg} / \mathrm{ekor} / \mathrm{hari}$. Untuk itu diperlukan upaya peningkatan produksi melakui aplikasi inovasi konsentrat pemacu pertumbuhan berbahan pakan lokal. Tujuan kegiatan ini adalah aplikasi penggunaan konsentrat pemacu pertumbuhan ternak sapi. Tim pengabdian dengan peternak bersama-sama merancang penyelesaian masalah dengan menetapkan upaya penyelesaian masalah melalui penggunaan konsentrat pemacu pertumbuhan. Metode penerapan meliputi (1) instruksional dan dialog melalui kegiatan program penyuluhan menggunakan teknik FGD (Focus Group Disscusion), (2) evaluasi kemajuan tingkat pengetahuan dan pemahaman materi, (3) pelatihan dan penerapan konsentrat pemacu pertumbuhan menggunakan mesin mixer, grinder dan chopper, (4) monitoring dan evaluasi berkelanjutan. Kesimpulan aplikasi penggunaan konsentrat pemacu pertumbuhan pada usaha penggemukan sapi telah berdampak terhadap mempercepat waktu penggemukan dari 4 bulan menjadi 2 bulan (50\%), meningkatkan pertambahan berat badan dari $0,25 \mathrm{~kg} / \mathrm{ekor} /$ hari menjadi $0,83 \mathrm{~kg} / \mathrm{ekor} / \mathrm{hari}(67,8 \%)$, peningkatan pendapatan peternak dari Rp 1.416.000 menjadi Rp 2.376 .000 (235,6\%), keuntungan yang diperoleh peternak meningkat dari Rp 891.050 menjadi Rp 1.390 .450 (56\%). Penggunaan inovasi konsentrat pemacu pertumbuhan mampu meningkatkan produksi dan memaksimalkan potensi genetis unggul sapi silangan serta meningkatkan pendapatan peternak.
\end{abstract}

Kata kunci : inovasi, konsentrat pemacu pertumbuhan, penggemukan, sapi potong

\section{ABSTRACT}

Maju Utomo and Ngudi Berkah livestock farmer groups Wonorejo Village Gondangrejo Karanganyar District trying to the Simpo and Limpo cattle feedlot. The problem faced by breeders is the daily weight gain of cows $0.2 \mathrm{~kg} / \mathrm{head} /$ day. For this reason, efforts are needed to increase production through the application of innovative growth-promoting concentrates made from a local feed. The purpose of the application is the use of growth-promoting concentrates. The dedicated team with the breeders jointly designs a solution to the problem by establishing a problem-solving effort through the use of growth-promoting concentrates. The methods of application include (1) instructional and dialogue through extension program activities using FGD (Focus Group Discussion) techniques, (2) evaluation of the level of knowledge and understanding of material progress, (3) training and manufacturing of growth-promoting concentrates, (4) ongoing monitoring and evaluation. Conclusion the application of the use of growth-promoting concentrates in cattle fattening efforts has an impact on accelerating the time of fattening from 4 months to 2 months (50\%), increasing weight gain from $0.25 \mathrm{~kg} / \mathrm{head} /$ day to $0.83 \mathrm{~kg} /$ head / day (67.8\%), an increase in livestock farmers' income from $R p$ 1,416,000 to $R p$ 2,376,000 (235.6\%), profits from farmers increased from $R p$ 891,050 to $R p$ 1,390,450 (56\%). The use of growth promoters concentrate innovation to increase production and maximize the potential of genetically superior cattle breeder crosses also increase revenue.

Keywords: innovation, growth-promoting concentrates, beef cattle, fattening 


\section{PENDAHULUAN}

Kelompok ternak "Ngudi Berkah" dan "Maju Utomo" di Desa Wonorejo, Karanganyar merupakan kelompok ternak penggemukan sapi potong sistem feedlot dan pembibitan sapi potong. Saat ini jumlah sapi potong total 50-75 ekor yang dipelihara keseluruhan di kedua kelompok 45 peternak dan setiap peternak memiliki 2-3 ekor sapi. Saat ini peternak di kedua kelompok mengalami permasalahan kesulitan dalam menambah dan meningkatkan pendapatan dari usaha peternakan sapi potong. Dari hasil pengamatan awal atau survei awal oleh tim pengabdian kepada masyarakat program Produk Teknologi yang di Desiminasikan ke Masyarakat (PTDM) Universitas Sebelas Maret diperoleh fakta bahwa pertambahan berat badan harian sapi hasil penggemukan rendah rata-rata 0,2 $\mathrm{kg} /$ ekor/hari dengan kondisi tubuh masuk kategori kurus-sedang dengan nilai Body Score Condition $(\mathrm{BCS})=2,5$ (1-5). Peternak hanya memberikan dedak sebanyak 2-3 kg/ekor/hari tanpa tambahan suplemen konsentrat. Di sisi lain sapi potong yang digunakan dari bangsa Simpo dan Limpo memiliki potensi genetik eksotik untuk dihasilkan pertambahan berat badan harian> $1 \mathrm{~kg} /$ ekor/hari. Usaha peternakan sapi potong di kelompok ternak "Ngudi Berkah" dan "Maju Utomo" Desa Wonorejo, Karanganyar mengalami kendala rendahnya hasil pertambahan berat badan harian sapi.

Keadaan ini jika tidak dilakukan upaya perbaikan manajemen pakan dengan pemberian konsentrat pemacu pertumbuhan maka peternak sapi potong "Ngudi Berkah" dan "Maju Utomo" di Desa Wonorejo, Karanganyar menghadapi permasalahan. Permasalahan tersebut meliputi potensi genetik pertambahan berat badan harian sapi potong untuk penggemukan tidak maksimal dimanfaatkan, produktivitas sapi penggemukan mengalami penurunan hingga $100 \%$, pendapatan usaha peternakan sapi potong tidak maksimal, dan tidak ada penambahan dan peningkatan pendapatan peternak. Untuk menyelesaikan permasalahan yang sedang dialami oleh peternak "Ngudi Berkah" dan "Maju Utomo" di Desa Wonorejo, Karanganyar, tim pengusul PTDM UNS bersama dengan peternak merancang solusi untuk menetapkan langkah aplikasi inovasi teknologi rekayasa pakan berbasis bahan pakan lokal melalui aplikasi teknologi suplementasi konsentrat pemacu pertumbuhan untuk penggemukan sapi potong.
Konsentrat pemacu pertumbuhan merupakan konsentrat yang dibuat dengan mencampur berbagai bahan pakan sumber protein, lemak dan energi sesuai yang dibutuhkan untuk memenuhi kebutuhan hidup pokok dan pertumbuhan sapi potong (Riyanto, et al.,2010a). Bahan pakan konsentrat pemacu pertumbuhan berasal dari bahan limbah pertanian seperti menir kedelai, dedak, bungkil sawit, limbah kulit kopi dan molases. Menir kedelai merupakan limbah dari hasil grading kedelai utuh yang digunakan sebagai sumber protein (Riyanto, et al.,2016). Dalam penggunaannya menir kedelai ini dilakukan proteksi protein menggunakan formaldehid (Lourenc, et al., 2010; Mahadevan, et al., 1983), proteksi terhadap protein agar lolos dari degradasi mikrobia rumen (Nobar, 2011; Oldham, et al.,1982). Formaldehid untuk proteksi protein kedelai (Stanton, et al.,1983) juga untuk menir kedelai dengan kadar kadar $37 \%$ (Riyanto, et al., 2010b). Komposisi konsentrat pemacu pertumbuhan terdiri atas bungkil sawit $15-20 \%$, kopra $15-20 \%$, bekatul $30-35 \%$, onggok 20-25\%, molases 5-5,5\%, mineral $1,5-2 \%$, urea $1,5-2 \%$, dan garam $0,5-1 \%$, dimana mengandung $14-15 \%$ protein, $60-70 \%$ TDN, 6-8\% serat kasar, 4-5\% lemak, 25-30\% BETN, dan 200-600 mg/100g asam lemak omega-3 (Riyanto, et al., 2010a; Riyanto, et al., 2016). Setelah diberikan sejumlah 5-7 kg per hari perekor sapi berat badan 400-450 kg selama 90120 hari dihasilkan pertambahan berat badan harian 1,08 kg/ekor/hari dan setelah sapi dipotong diperoleh daging dengan kadar asam lemak omega-3 750-900 mg/100 g kadar asam lemak omega-6 sebesar $20,03 \mathrm{mg} / 100 \mathrm{~g}$ dan kolesterol 55,15 mg/100 g (Riyanto, et al., 2010a; Riyanto, et al., 2017). Kedua konsentrat sudah memperoleh nomor pendaftaran paten atas nama ketua inventor Ir. Joko Riyanto, MP dengan nama dan nomer pendaftaran paten sebagai berikut : (1) "Konsentrat Asam Lemak Omega-3 Untuk Suplementasi Pakan Sapi Potong dan Metode Pembuatannya" Nomor P002012006 tahun 2012 dan (2) Konsentrat Asam Lemak Omega-6 Untuk Suplementasi Pakan Sapi Potong dan Metode Pembuatannya Nomor P00201304602 tahun 2013.

Dampak positif program PTDM di "Ngudi Berkah" dan "Maju Utomo" di Desa Wonorejo, Karanganyar adalah pemanfaatan bahan pakan lokal sebagai sumber bahan pakan penggemukan sapi potong, penggunaan bahan pakan lokal diformulasi dan diterapkan sebagai pakan suplemen pakan untuk penggemukan sapi 
potong, serta peningkatan kesejahteraan peternak. Tujuan PTDM UNS ini untuk meningkatkan produktivitas pengggemukan sapi potong dan pendapatan peternak sapi potong di KTT "Ngudi Berkah" dan "Maju Utomo" Desa Wonorejo, Kecamatan Gondangrejo, Kabupaten Karanganyar, Jawa Tengah.

\section{METODE}

Program Pengabdian PTDM UNS ini dilaksanakan dengan metode penyuluhan, pelatihan dan demonstrasi atau percontohan, aplikasi atau penerapan, dan monitoring dan evaluasi berkelanjutan. Kegiatan pengabdian ini dilaksanakan secara bertahap dan berkelanjutan. Kegiatan awal dilakukan sosialisasi program untuk kedua kelompok, yang dihadiri perangkat Desa Wonorejo dan tenaga penyuluh lapang Kecamatan Gondangrejo serta mahasiswa pendamping.

Kegiatan penyuluhan menggunakan teknik Focus Group Disscusion (FGD) melalui instruksional dan dialog disertai dengan evaluasi kemajuan tingkat pengetahuan dan pemahaman materi aplikasi pengunaan konsentrat pemacu pertumbuhan untuk penggemukan sapi potong. Evaluasi penyuluhan digunakan untuk menilai suatu program penyuluhan pertanian. Evaluasi penyuluhan dilakukan dengan proses pengumpulan data, penentuan ukuran, penilaian serta perumusan keputusan yang digunakan untuk perbaikan atau penyempurnaan perencanaan berikutnya yang lebih lanjut demi tercapainya tujuan dari program penyuluhan pertanian (Mardikanto, 2014). Evaluasi penyuluhan bermanfaat agar program penyuluhan berjalan lebih baik dan mencapai tujuan yang maksimal (Herawati, 1999). Evaluasi penyuluhan ini dapat digunakan untuk mengetahui suatu perubahan keadaan benarbenar disebabkan oleh kegiatan penyuluhan atau adanya faktor-faktor penyebab lain yang mempengaruhinya (Haryadi, 1997; Brahim, et al., 2003).

Pengukuran perubahan penerimaan hasil penyuluhan dan pelatihan menggunakan metode Analyzing Change/Gain Score (ACS) (g) atau nilai perubahan pembelajaran yang untuk menilai hasil pembelajaran penyuluhan dan pelatihan dilakukan penilaian menurut metode Hake, et al., (1999). ACS yaitu cara membuat score atau penilaian berdasarkan analisis nilai perubahan sebelum tes (pre-test) dan sesudah tes (post-test), kemudian melakukan klasifikasi perubahan hasil pembelajaran disebut dengan nilai analisis perubahan. Metode ACS dapat memberikan gambaran umum peningkatan skor hasil pembelajaran antara sebelum dan sesudah dilakukan tes ketika melakukan penyuluhan dan pelatihan. Kemampuan pembelajaran peternak melaui ACS dapat untuk melihat dan menentukan sampai seberapa besar perkembangan pembelajaran terhadap amteri yang telah diberikan selama mengikuti penyuluhan dan pelatihan.

$$
\text { Langkah penilaian ACS adalah }
$$
menghitung nilai jawaban peserta penyuluhan/pelatihan yang benar pada setiap soal tes, menghitung nilai mentah dari hasil pretest dan posttest, menghitung nilai perubahan antara nilai rata-rata pre-test dan post-test secara keseluruhan dengan menggunakan rumus :

Analyzing change/gain score (ACS) $(\mathrm{g})=$

$$
\frac{\text { Nilai posttest - Nilai pretest }}{\text { Nilai maksimum - Nilai pretest }}
$$

Kriteria Analyzing change/gain score (ACS) (g) (Hake et al., 1999):

- $\mathrm{g}<0,3$ peningkatan nilai perubahan rendah

- $0,7>\mathrm{g}>0,3$ peningkatan nilai perubahan sedang

- $\mathrm{g}>0,7$ peningkatan nilai perubahan tinggi

Materi penyuluhan meliputi pengenalan bahan-bahan pakan berbagai sumber nutrien yang dapat diberikan untuk penggemukan sapi, pengenalan nutrien bahan pakan, pengenalan alat mixer atau pencampur pakan dan alat grinder atau pemecah bahan pakan butiran, membuat formula sederhana ransum penggemukan sapi dengan penambahan konsentrat pemacu pertumbuhan, menghitung keuntungan dan kerugian pemberian konsentrat pemacu pertumbuhan, dan cara memproduksi dan menyimpan konsentrat pemacu pertumbuhan.

Kegiatan pelatihan dan demonstrasi atau percontohan dilaksanakan setelah peternak di kedua kelompok menerima penyuluhan. Metode pelatihan dilaksanakan dengan cara menerapkan langsung atau praktek dari materi penyuluhan yang telah dilakukan sebelumnya. Selama dua hari peternak dilatih menentukan dan memilih bahan pakan yang baik dan tepat untuk dijadikan sebagai konsentrat, membuat formula ransum sesuai dengan kebutuhan penggemukan sapi, menyusun formula konsentrat pemacu 
pertumbuhan dan ransum, menyusun dan mencampur dengan benar menggunakan mesin pencampur, menyimpan konsentrat pemacu pertumbuhan dengan benar. Peserta yang telah hadir berjumlah 20 orang anggota kedua kelompok, tim PTDM, perangkat Desa Wonorejo, Tenaga Penyuluh Peternakan dan Pertanian Kecamatan Gondangrejo Kabupaten Karanganyar, dan 5 orang mahasiswa.

Aplikasi penggunaan konsentrat pemacu pertumbuhan dilaksanakan dengan cara peternak membuat formula dan mencampur bahan-bahan pakan sesuai dengan takaran. Bahan pakan dibuat dengan formulasi dalam $100 \mathrm{~kg}$ terdiri atas $39 \mathrm{~kg}$ bekatul, $17 \mathrm{~kg}$ bungkil sawit, $20 \mathrm{~kg}$ kulit kopi, $21 \mathrm{~kg}$ pollard, $2 \mathrm{~kg}$ tetes tebu, dan 1 $\mathrm{kg}$ mineral dan vitamin. Harga konsentrat pemacu pertumbuhan harga $\mathrm{Rp} 2.700$ per $\mathrm{kg}$. Kandungan nutrien protein $11 \%$, lemak $4 \%$, serat kasar $12 \%$, abu 7\%, BETN 55\% dan TDN $70 \%$. Bahan pakan merupakan hasil limbah pertanian dan olahannya yang dibeli dari toko pakan di sekitar wilayah Karanganyar dan semua bahan pakan selalu tersedia sepanjang waktu.

Bahan pakan dicampur menggunakan mesin pencampur pakan horisontal dengan cara memasukkan bahan pakan dengan takaran yang paling sedikit sampai takaran terbanyak, lalu dimasukkan dalam mesin pencampur dan diaduk sampai homogen selama 10 menit. Setiap pencampuran konsentrat pemacu pertumbuhan sebanyak $100 \mathrm{~kg}$ kemudian dikemas dan disajikan untuk masing-masing sapi sesuai dengan kebutuhan. Penerapan konsentrat pemacu pertumbuhan dilaksanakan untuk penggemukan sapi potong sebanyak 16 ekor milik peternak di kandang kelompok Ngudi Berkah. Bangsa sapi potong adalah Sapi Peranakan Simental-Ongole, sapi Peranakan Limousin-Ongole, dan sapi Peranakan Ongole.

Berat badan sapi diketahui dengan menggunakan menggunakan pita ukur Animeter khusus untuk sapi potong. Berat badan sapi diketahui dengan cara melingkarkan pita ukur Animeter pada bagian dada di belakang bahu atau pada tulang rusuk 4-5 untuk diketahui lingkar dada. Ukuran lingkar dada sapi dalam satuan sentimeter kemudian dilihat pada skala berat badan sapi yang ada dibagian pita ukur Animeter satuan kilogram (Riyanto, et al., 2010b).

Sapi potong digemukkan selama 60 hari dengan masa adaptasi konsentrat pemacu pertumbuhan selama 2 minggu. Pakan yang diberikan untuk penggemukan terdiri dari jerami padi fermentasi sebanyak 8-10 kg dan konsentrat pemacu pertumbuhan sebanyak 7-8 kg per ekor per hari. Konsentrat pemacu pertumbuhan diberikan dua kali setiap hari. Berat badan diukur setiap dua minggu selama pemberian konsentrat pemacu pertumbuhan. Mesin campur atau mixer yang digunakan untuk pencampuran konsentrat, pelaksanaan penilaian ACS dan pita ukur Animeter untuk menentukan berat badan sapi potong dapat dilihat pada Gambar 1.

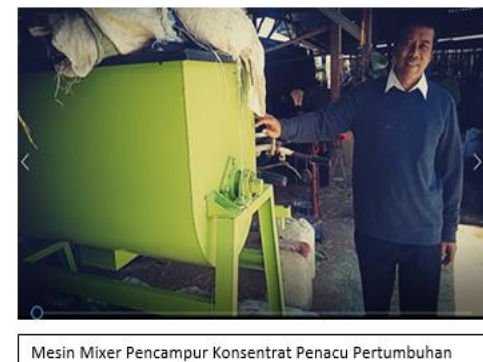

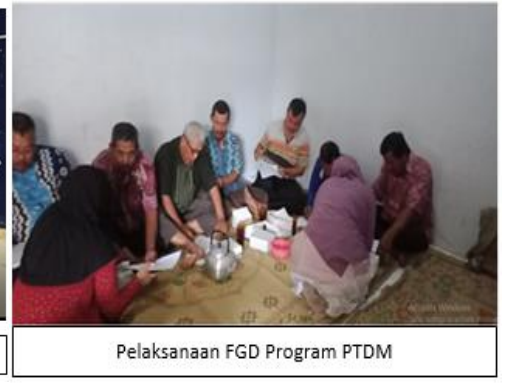

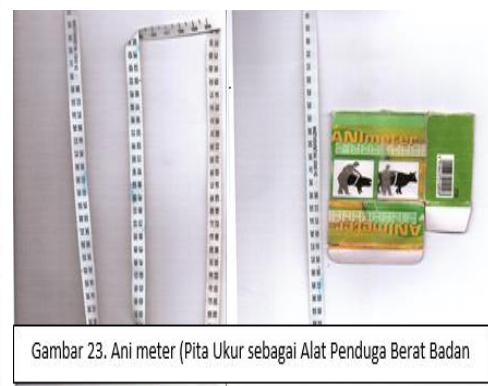

Gambar 1. Mesin pencampur pakan (mixer), pelaksanaan penilaian ACS dan pita ukur Animeter penentuan berat badan sapi

Pelaksanaan kegiatan monitoring dan evaluasi program penerapan penggunaan konsentrat pemacu pertumbuhan dilakukan secara rutin dan berkelanjutan. Setiap bulan tim pengabdian melakukan monitoring dan evaluasi terhadap kegiatan penerapan penggunaan konsentrat pemacu pertumbuhan bersama-sama dengan anggota dan pengurus kedua kelompok dan didampingi tenaga Penyuluh Lapang Pertanian
Peternakan Kecamatan Gondangrejo. Selama kegiatan monitoring dan evaluasi ini tenaga penyuluh lapang juga ikut serta aktif memantau dan memberikan saran-saran dan masukan kepada peternak dalam hal penggemukan sapi potong yang dilakukan oleh kedua kelompok. 


\section{HASIL DAN PEMBAHASAN}

\section{Kegiatan Koordinasi dan Sosialisasi}

Kegiatan sosialisasi dilakukan dengan metode FGD dan penyuluhan. Tempat pelaksanaan di Rumah Ketua KTT Ngudi Berkah di Desa Wonorejo, Karanganyar. Peserta terdiri dari Kepala Desa Wonorejo dan staf, Ketua KTT dan semua angggota, tim PTDM UNS, Petugas Penyuluh Pertanian dan Peternakan serta mahasiswa Program Studi Peternakan yang dilibatkan dalam kegiatan PTDM. Tim memberikan penjelasan kepada pengurus kelompok ternak sapi potong tentang kegiatan yang akan dilaksanakan di kelompok tersebut dan mengemukakan hal-hal yang perlu dipersiapkan untuk menjalankan program. Selama sosialisasi telah dilakukan pengukuran daya terima dan pengetahuan mengenai program aplikasi inovasi teknologi konsentrat pemacu pertumbuhan. Metode yang efektif untuk melakukan alih teknologi atau inovasi melalui cara komunikasi dengan masyarakat menggunakan metode FGD (Kartasapoetra, 1994). Untuk mengukur sikap masyarakat terhadap penyampaian informasi atau inovasi diperlukan upaya pendekatan penyebaran informasi, penyuluhan atau pelatihan disertai dengan pengukuran parameter yang terukur (Mueller, 1986).

\section{Aplikasi pembuatan dan penggunaan konsentrat pemacu pertumbuhan untuk penggemukan sapi potong di Karanganyar}

Kegiatan penyuluhan proses pembuatan konsentrat pemacu pertumbuhan telah dilaksanakan dengan topik "Penggunaan Konsentrat Pemacu Pertumbuhan untuk Meningkatkan Berat Badan dan Keuntungan Usaha Penggemukan Sapi Potong" bertempat di rumah ketua KTT Ngudi Berkah Desa Wonorejo. Materi meliputi pengenalan bahanbahan pakan berbagai sumber nutrien yang dapat diberikan untuk penggemukan sapi, pengenalan nutrien bahan pakan, membuat formula sederhana ransum penggemukan sapi dengan penambahan konsentrat pemacu pertumbuhan, menghitung keuntungan dan kerugian pemberian konsentrat pemacu pertumbuhan, dan cara memproduksi dan menyimpan konsentrat pemacu pertumbuhan). Peserta peternak kedua KTT, tim PTDM, perangkat Desa Wonorejo, Tenaga Penyuluh Peternakan dan Pertanian, dan mahasiswa. Teknik penyuluhan dilaksanakan dengan FGD dan diskusi serta penilaian daya terima inovasi dan kemajuan pengetahuan penerimaan inovasi. Cara pengukuran kemajuan pemahaman pengetahuan dilakukan dengan menghitung persentase hasil pre-test dan posttest. Soal dibuat dengan model pilihan berganda dengan jumlah soal 10 dan disediakan 3 pilihan jawaban dengan jawaban salah satunya benar. Soal pre-test dan post-test sama. Pre-test diberikan sebelum penyuluhan dan post-test dilakukan setelah penyuluhan.

Pelatihan pembuatan dan produksi konsentrat pemacu pertumbuhan telah dilaksanakan kepada anggota KTT Ngudi Berkah dan Maju Utomo bertempat di kandang kelompok KTT Ngudi Berkah di Desa Wonorejo. Topik pelatihan adalah "Aplikasi pembuatan dan produksi konsentrat pemacu pertumbuhan untuk penggemukan sapi. Materi pelatihan meliputi proses pembuatan konsentrat pemacu pertumbuhan. Peserta terdiri atas peternak kedua KTT, tim PTDM, perangkat Desa Wonorejio, Tenaga Penyuluh Peternakan dan Pertanian, dan mahasiswa. Teknik pelatihan dilaksanakan dengan cara mengerjakan pembuatan jerami padi fermentasi sesuai dengan petunjuk). Praktek pembuatan konsentrat pemacu pertumbuhan ini didampingi oleh Tim PTDM dan mahasiswa. Tabel 1 menampilkan hasil pre-test, post-test dan nilai perubahan pembelajaran atau ACS penyuluhan dan pelatihan.

Tabel 1 tampak bahwa dari hasil penghitungan ACS atau perubahan nilai pembelajaran pada kegiatan penyuluhan sebesar $\mathrm{ACS}=0,92$ dan pelatihan sebesar $\mathrm{ACS}=0,95$. Hal ini menunjukkan bawah peternak mempunyai kemampuan peningkatan nilai perubahan tinggi yang baik untuk kegiatan penyuluhan maupun pelatihan aplikasi inovasi penggunaan konsentrat pemacu pertumbuhan sapi potong. Peternak sapi potong di KTT Ngudi Berkah dan Maju Utomo mampu menerima dan memahami tentang bahan-bahan pakan berbagai sumber nutrien yang dapat diberikan untuk penggemukan sapi, kebutuhan nutrien bahan pakan, cara kerja alat mixer atau pencampur pakan dan alat grinder atau pemecah bahan pakan butiran, membuat formula sederhana ransum penggemukan sapi dengan penambahan konsentrat pemacu pertumbuhan, menghitung keuntungan dan kerugian pemberian konsentrat pemacu pertumbuhan, dan cara memproduksi dan menyimpan konsentrat pemacu pertumbuhan. Peternak juga mampu menentukan dan memilih bahan pakan yang baik 
dan tepat untuk dijadikan sebagai konsentrat, membuat formula ransum sesuai dengan kebutuhan penggemukan sapi, menyusun formula konsentrat pemacu pertumbuhan dan ransum, menyusun dan mencampur dengan benar menggunakan mesin pencampur, menyimpan konsentrat pemacu pertumbuhan dengan benar. Menurut Hake, et al., (1999) mengatakan bahwa setelah dilakukan pre-tes dan post-tes berupa materi pembelajaran dengan nilai ACS (g)> 0,7 maka menunjukkan bahwa peserta memiliki kemampuan yang tinggi dalam menerima materi suatu kursus.

Tabel 1. Hasil penilaian kegiatan penyuluhan dan pelatihan aplikasi konsentrat pemacu pertumbuhan program PTDM

\begin{tabular}{lrrrrrr}
\hline \multirow{2}{*}{$\begin{array}{c}\text { Komponen } \\
\text { penilaian }\end{array}$} & \multicolumn{3}{c}{ Kegiatan Penyuluhan } & \multicolumn{2}{c}{ Kegiatan Pelatihan } \\
\cline { 2 - 7 } & $\begin{array}{c}\text { Nilai } \\
\text { pre-test }\end{array}$ & $\begin{array}{c}\text { Nilai } \\
\text { post-test }\end{array}$ & $\begin{array}{c}\text { Nilai } \\
\text { perubahan } \\
\text { pembelajaran } \\
\text { atau ACS(g) }\end{array}$ & $\begin{array}{c}\text { Nilai } \\
\text { pre- } \\
\text { test }\end{array}$ & $\begin{array}{c}\text { Nilai } \\
\text { post-test }\end{array}$ & $\begin{array}{c}\text { Nilai } \\
\text { perubahan } \\
\text { pembelajaran } \\
\text { atau ACS (g) }\end{array}$ \\
\hline Rata-rata & 2 & 8,5 & & 2 & 8,7 & \\
Nilai minimum & 1 & 8 & 0,92 & 2 & 8 & 0.95 \\
Nilai & 4 & 9 & & 3 & 9 & \\
maksimum & & & & & & \\
\hline
\end{tabular}

Aplikasi pembuatan dan penggunaan konsentrat pemacu pertumbuhan untuk penggemukan sapi potong

Percontohan dan penerapan penggunaan jerami padi fermentasi dan konsentrat pemacu pertumbuhan untuk penggemukan sapi potong. Peternak bersama membuat jerami padi fermentasi dan konsentrat pemacu pertumbuhan di kandang kelompok sesuai dengan hasil pelatihan. Jerami padi fermentasi dan konsentrat pemacu pertumbuhan yang telah dibuat kemudian sebagian disimpan dan sebagian lagi diberikan untuk penggemukan sapi.

Konsentrat pemacu pertumbuhan merupakan campuran dari berbagai bahan pakan limbah yang sangat mudah dibeli dan diperoleh dari daerah sekitar di KTT Ngudi Berkah dan Maju Utomo Desa Wonorejo. Kulit kopi dan bungkil sawit sebelumnya digiling menggunakan mesin grinder dan semua bahan dicampur dengan menggunakan mesin mixer. Sapi yang diberi jerami padi fermentasi dan konsentrat pemacu pertumbuhan adalah sapisapi milik anggota kedua kelompok. Kegiatan ini dijadikan sebagai model atau percontohan untuk anggota kelompok lainnya. Jumlah pemberian diberikan berdasarkan berat badan sapi. Harga sapi didasarkan atas harga berat hidup sapi yang berlaku pada saat penggemukan sebesar Rp.
48.000. Harga sapi ditentukan dengan mengalikan berat badan hidup dengan harga berat hidup sapi. Penentuan dilakukan oleh "blantik" atau juru taksir harga sapi dari pasar hewan Tegalyoso. Setiap ekor sapi diberikan sebanyak $7 \mathrm{~kg}$ untuk berat sapi $350-400 \mathrm{~kg}$. Hasil dari aplikasi penggunaan jerami padi fermentasi dan konsentrat pemacu pertumbuhan di KTT Ngudi Berkah dan Maju Utomo diantaranya dapat dilihat dari performa produksi pertambahan berat badan harian (kg/ekor/hari) dan tampilan berat awal dan akhir penggemukan serta dampak terhadap nilai ekonomisnya seperti harga awal dan akhir penggemukan juga keuntungan yang diperoleh setiap ekor setiap bulan.

Untuk evaluasi kegiatan program PTDM aplikasi inovasi fermentasi jerami padi fermentasi dan konsentrat pemacu pertumbuhan dilaksanakan dengan membandingkan antara penggemukan program PTDM dengan penggemukan yang sudah dilaksanakan peternak sebelumnya. Program tanpa aplikasi JPF (jerami padi fermentasi) dan konsentrat pemacu pertumbuhan (KPP) diperoleh dari hasil wawancara dan pencatatan pada peternak kedua kelompok. Hasil perbandingan dapat dilihat pada Tabel 2. 
Tabel 2. Performa dan hasil usaha penggemukan sapi potong tanpa dan menggunakan aplikasi JPF dan KPP di KTT Ngudi Berkah dan Maju Utomo

\begin{tabular}{|c|c|c|c|c|}
\hline Parameter & $\begin{array}{c}\text { Setelah } \\
\text { penggunaan } \\
\text { konsentrat } \\
\text { pemacu } \\
\text { pertumbuhan } \\
\text { (A) }\end{array}$ & $\begin{array}{l}\text { Sebelum } \\
\text { penggunaan } \\
\text { konsentrat } \\
\text { pemacu } \\
\text { pertumbuhan (B) }\end{array}$ & $\begin{array}{l}\text { Perbedaaan } \\
\text { A dengan B }\end{array}$ & $\begin{array}{c}\text { Persentase } \\
\text { perbedaan } \\
(\%) \mathrm{A} \\
\text { dengan B }\end{array}$ \\
\hline Lingkar Dada awal (cm) & 174 & 174 & 0 & 0 \\
\hline Lingkar Dada akhir (cm) & 180 & 176 & 4 & 2,4 \\
\hline Berat awal (kg) & 426 & 426 & 0 & 0 \\
\hline Berat akhir (kg) & 475 & 455 & 20 & 4,4 \\
\hline Harga awal (Rp/ekor) & 20.424 .000 & 20.424 .000 & 0 & 0 \\
\hline Harga akhir (Rp/ekor) & 22.800 .000 & 21.840 .000 & 960.000 & 4,4 \\
\hline Lama penggemukan (bulan) & 2 & 4 & 2 & 50 \\
\hline Harga sapi (Rp/kg berat badan) & 48.000 & 48.000 & 0 & 0 \\
\hline Harga pakan $(\mathrm{Rp} / \mathrm{kg})$ & 2.700 & 2.300 & 400 & 17,4 \\
\hline $\begin{array}{l}\text { Pertambahan berat badan } \\
\text { (kg/ekor) }\end{array}$ & 50 & 30 & 20 & 67,8 \\
\hline $\begin{array}{l}\text { Pertambahan berat badan harian } \\
\text { (kg/ekor/hari) }\end{array}$ & 0,83 & 0,25 & 0,58 & 235,6 \\
\hline Pendapatan (Rp/ekor) & 2.376 .000 & 1.416 .000 & 960.000 & 67,8 \\
\hline $\begin{array}{l}\text { Biaya pakan (Rp/ekor) selama } \\
\text { penggemukan }\end{array}$ & 935.550 & 474.950 & 460.600 & 97,0 \\
\hline $\begin{array}{l}\text { Biaya non pakan } \\
\text { (Rp/ekor)selama } \\
\text { penggemukan }\end{array}$ & 50.000 & 50.000 & 0 & 0 \\
\hline $\begin{array}{l}\text { Biaya penggemukan (Rp/ekor) } \\
\text { selama penggemukan }\end{array}$ & 985.550 & 524.950 & 460.600 & 87,7 \\
\hline $\begin{array}{l}\text { Biaya penggemukan } \\
\text { (Rp/ekor/bulan) }\end{array}$ & 492.775 & 131.238 & 361.538 & 275,5 \\
\hline $\begin{array}{l}\text { Keuntungan (Rp/ekor) selama } \\
\text { penggemukan }\end{array}$ & 1.390 .450 & 891.050 & 499.400 & 56,0 \\
\hline Keuntungan (Rp/ekor/bulan) & 695.225 & 445.525 & 249.700 & 56,0 \\
\hline
\end{tabular}

Tabel 2, hasil analisis usaha penggemukan sapi potong tampak bahwa aplikasi inovasi penggunaan jerami padi fermentasi dan konsentrat pemacu pertumbuhan berdampak terhadap memperpendek lama penggemukan dari 4 bulan menjadi 2 bulan (50\%), pertambahan berat badan meningkat dari 0,25 $\mathrm{kg} / \mathrm{ekor} / \mathrm{hari}$ menjadi $0,83 \mathrm{~kg} / \mathrm{ekor} / \mathrm{hari}(67,8 \%)$, pendapatan peternak dari Rp 1.416 .000 menjadi Rp 2.376.000 (235,6\%), keuntungan meningkat dari Rp 891.050 menjadi Rp 1.390.450 (56\%), walaupun biaya penggemukan lebih banyak $275,5 \%$ menggunakan konsentrat pemacu pertumbuhan. Kegiatan aplikasi konsentrat pemacu pertumbuhan program PTDM di KTT Ngudi Berkah dan Maju Utomo Karanganyar dapat dilihat pada Gambar 2.

Pencapaian pertambahan berat badan harian sapi potong sangat ditentukan oleh pakan yang dikonsumsi oleh sapi. Sumber pakan untuk pertumbuhan dapat disediakan dari konsentrat. Konsentrat pemacu pertumbuhan adalah konsentrat yang dihasilkan pengusul PTDM dari penelitian sumber dana DRPM Dikti Skim Strategi Nasional pada tahun 2009-2010, dan hibah penelitian IPTEK pada tahun 2015-1016. Konsentrat pemacu pertumbuhan berbasis bahan kaya asam lemak omega-3 dan omega- 6 telah mampu menghasilkan pertambahan berat badan harian 1,08 kg/ekor/hari sapi Simpo (Riyanto, et al., 2010a; Riyanto, et al., 2010b), dihasilkan pertambahan berat badan harian untuk sapi Simpo 1,00, sapi Limpo 1,28 dan sapi PO 0,75 $\mathrm{kg} / \mathrm{ekor} / \mathrm{hari}$ (Riyanto, et al., 2016). Konsentrat pemacu pertumbuhan hasil penelitian dihasilkan peningkatan pertambahan berat badan harian sapi yang dipelihara dalam usaha peternakan rakyat (Widyawati, et al., 2008; Widyawati, et 
al., 2011). Konsentrat pemacu pertumbuhan dihasilkan daging segar yang tinggi kadar protein dan asam lemak tak jenuh ganda serta rendah lemak dan kolesterol (Riyanto. et al.,2010a; Riyanto. et al., 2016). Bahan pakan sebgai sumber protein tinggi untuk dihasilkan asam lemak untuk meningkatkan pertumbuhan berasal dari menir kedelai (Perdana, et al.,2013; Riyanto et al., 2010a). Protein dari menir kedelai sebelumnya dilakukan proteksi untuk meloloskan protein dari degradasi rumen sehingga dapat lolos sampai diserap diusus halus (Stanton, et al., 1983; Palizdar et al.,2012; Riyanto et al.,2016). Hal ini menunjukkan bahwa penggunaan inovasi jerami padi fermentasi dan konsentrat pemacu pertumbuhan mampu meningkatkan produksi dan memaksimalkan potensi genetis unggul sapi silangan juga meningkatkan kesejahteraan peternak.

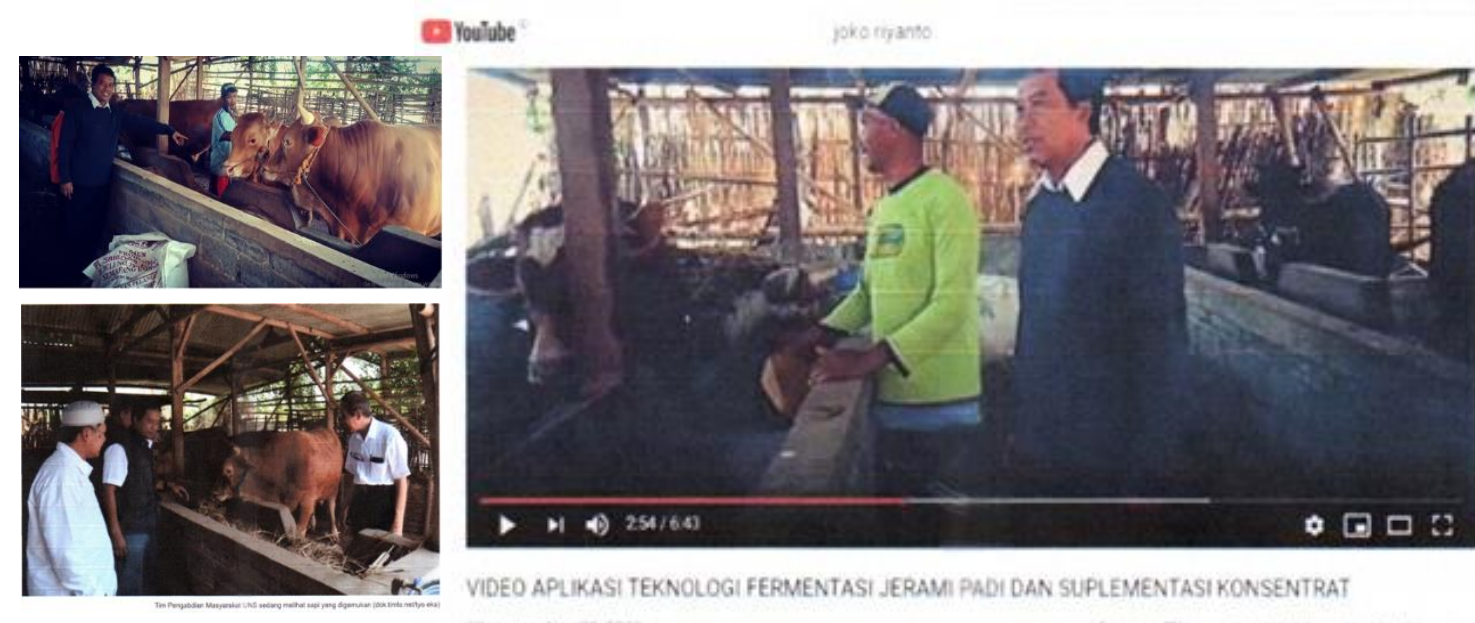

Gambar 2. Pelaksanan aplikasi konsentrat pemacu pertumbuhan pada KTT Ngudi Berkah dan Maju Utomo Karanganyar

\section{KESIMPULAN}

Aplikasi inovasi penggunaan konsentrat pemacu pertumbuhan pada usaha penggemukan sapi telah berdampak terhadap percepatan waktu penggemukan dari 4 bulan menjadi 2 bulan (50\%), meningkatkan pertambahan berat badan dari $0,25 \mathrm{~kg} / \mathrm{ekor} /$ hari menjadi $0,83 \mathrm{~kg} / \mathrm{ekor} / \mathrm{hari}$ $(67,8 \%)$, peningkatan pendapatan peternak dari Rp 1.416.000 menjadi Rp 2.376.000 (235,6\%), keuntungan yang diperoleh peternak meningkat dari Rp 891.050 menjadi Rp 1.390 .450 (56\%). Penggunaan inovasi konsentrat pemacu pertumbuhan mampu meningkatkan produksi dan memaksimalkan potensi genetis unggul sapi silangan serta meningkatkan pendapatan peternak.

\section{UCAPAN TERIMAKASIH}

Terimakasih diucapkan kepada Direktorat Riset dan Pengabdian Masyarakat Kementerian Riset, Teknologi Dan Pendidikan Tinggi Indonesia atas pendanaan pengabdian Produk Teknologi Yang Didesiminasikan ke Masyarakat
(PTDM) Kementerian Riset, Teknologi dan Pendidikan Tinggi Tahun Anggaran 2019.

\section{DAFTAR PUSTAKA}

Brahim, J. T. Ahmad, S dan Harpowo. 2003. Komunikasi Penyuluh Pertanian. Banyumedia Publishing dan Universitas Muhammmadiyah. Malang Press. Malang.

Haryadi, F.T. 1997. Efektivitas Penyuluhan Pada Peternakan Sapi Potong Dua Model Perkampungan. Tesis. Fakultas Pascasarjana. Institut Pertanian. Bogor.

Herawati. 1999. Dasar-dasar Komunikasi untuk Penyuluhan. Universitas Atmajaya. Yogyakarta.

Hake, R. R. (1999). Analyzing change/gain score. Dept. of Physics, Indiana Un https://www.physics.indiana.edu/ sdi/An alyzingChange-Gain.pdf

Kartasapoetra, A.G. 1994. Teknologi Penyuluhan pertanian. Bumi Aksara. Jakarta. 
Lourenc, M., E. Ramos-Morales and R. J. Wallace- 2010. The role of microbes in rumen lipolysis and biohydrogenation and their manipulation. Animal (2010), 4(7):1008-1023 \&The Animal Consortium 2010.

Mahadevan, S., R.M. Teather., J.D. Erfle and F.D. Sauer. 1983. Effect of formaldehyde treatment of soybean meal on rates of protein degradation and microbial protein concentration in bovine rumen. Can. J. Anim. Sci. 63: 181-190,

Mardikanto, Totok. 2014. CSR (Corporate Social Responsibility)(Tanggungjawab Sosial Korporasi). Bandung: Alfabeta.

Mueller, D.J. 1986. Mengukur Sikap Sosial : Pegangan Untuk Penelitidan Praktisi. Bumi aksara. Jakarta.

Nobar, R.S. 2011. Ruminal dry matter degradability of treated soybean meal as source of escape protein. African $\mathrm{J}$. Biotech. 10(41):8090-8092

Oldham, J. D., I. C. Hart and J.A. Bines. 1982. Formaldehide-treated proteins or dairy cows-effects on blood hormone concentration. Er. J. Nutr. 48:543-547.

Palizdar, M.H., H. Sadeghipanah, H. Amanlou, H.R. Mohammadian-Tabrizi and A. Mirhadi. 2012. Effect of soybean meal coated with fat on in vitro organik atter fermentation and gas production. J. Anim. and Vet. Adv, 11 (2) : 171-180.

Perdhana, P. W., J. Riyanto, A. Ratriyanto, S. D. Widyawati dan W. P. S. Suprayogi. 2013. Pengaruh Penggunaan Tepung Ikan dan Menir Kedelai Terproteksi dalam Ransum terhadap Kecernaan Nutrien pada Sapi Persilangan Simmental Peranakan Ongole Jantan Tropical Animal Husbandry ISSN 2301-992167 Vol. 2, No. 1:1-7

Riyanto, J., S. D. Widyawati, dan W. Pratitis. 2010a. Suplementasi Pufa (Poly Unsaturated Fatty Acid) Dalam Konsentrat Dari Bahan Pakan Lokal Pada Usaha Feedlot Sapi Silangan Berbasis Pakan Basal Jerami Padi Fermentasi Untuk Dihasilkan Daging Sapi Rendah Lemak Dan Kolesterol Serta Tinggi Asam Lemak Tak Jenuh Laporan Penelitian. Strategi Nasional Batch II, DRPM Dikti Diknas

2010b. Feedlot System Application for Ongole-Simmental Cross Fattening of
Rice Straw Fermented Based and Growth Promoting Concentrate Supplementation in the Pattern of Integrated Sustainability Farming System with the Concept of Zero Waste-LEISA to Improve the Welfare Livestock Farmers Group in Indonesia Proceedings Animal Science Congress. the 14th Animal Science Congress of the Asian-Australasian Association of Animal Production Societies (AAAP) at National Pingtung University of Science and Technology (NPUST), Pingtung, Taiwan from August 23 to 27, 2010 ISBN : 978-957-30207-5-2

Riyanto, J., S. D. Widyawati, dan A. Pramono. 2016. Pengembangan Konsentrat Omega3 Dan Omega-6 Berbasis Bahan Pakan Lokal Sebagai Feed Supplement Untuk Percepatan Produksi Dan Kualitas Daging Sapi Potong (Tahun-2). Laporan Penelitian. Riset Pengembangan Ilmu Pengetahuan Dan Teknologi (Iptek) DRPM Dikti

Riyanto, J., dan Sudibya. 2017. Suplementasi Konsentrat Asam Lemak Omega-3 Dan 6 Untuk Percepatan Produktivitas Dan Dihasilkan Daging Kambing Dan Domba Kaya Asam Lemak Omega-3 Dan -6 Serta Rendah Kolesterol (Tahun-1). Laporan Penelitian. Hibah Penelitian Unggulan Perguruan Tinggi DPRM Kemenristek

Riyanto, J., S.D. Widyawati, A. Pramono, Lutojo dan Riyanti. 2017. Penampilan Produksi Penggemukan Feedlot Sapi Persilangan Simental-Ongole Jantan Diberi Ransum Menir Kedelai-Minyak Ikan Lemuru Terproteksi Sains

Peternakan: Jurnal Penelitian Ilmu Peternakan 1693-8828 (Print) 2548-932X (Online) 15 (1), 22-28

Stanton T. L. , F. N. Owens and K. S. Lusby. 1983. Formaldehyde-treated soybean meal for ruminants grazing winter range grass. J. Anim. Sci; 56:6-14.

Widyawati, S.D. dan W. Pratitis. 2008. Perbaikan produktivitas ternak ruminansia pada peternakan rakyat melalui pemberian Growth Promoting Feed. Hibah Pekerti. Dikti Kemendikbud Widyawati, S.D. dan W. Pratitis. 2011. Percepatan Penggemukan Ternak Sapi Melalui Suplementasi Sumber Protein Dengan Metode Slow ReleasedAmmonia. Hibah Pekerti DRPM. 